\title{
Modernising educational programmes in ICT based on the Tuning methodology
}

\author{
Alexander Bedny, Liliya Erushkina, and Oleg Kuzenkov
}

\begin{abstract}
An analysis is presented of the experience of modernising undergraduate educational programs using the TUNING methodology, based on the example of the area of studies "Fundamental computer science and information technology" (FCSIT) implemented at Lobachevsky State University of Nizhni Novgorod (Russia). The algorithm for reforming curricula for the subject area of information technology in accordance with the TUNING methodology is explained. A comparison is drawn between the existing Russian and European standards in the area of ICT education, including the European e-Competence Framework, with the focus on relevant competences. Some guidelines for the preparation of educational programmes are also provided.
\end{abstract}

Keywords: TUNING methodology; information and communication technology; competence system; ICT; Tuning; modular curriculum.

\section{Bachelors programme in Information Technology at UNN}

Creating a single European area of higher education and the introduction of new principles in higher education is quite a challenge, both for Russia and for Europe as a whole. Despite the importance of this task, the ideas and principles underlying the modern transformation in higher education are not always implemented effectively in specific educational process. It should also be noted that each subject area of education has significant specific features, and methods of reforming should take into account the peculiarities of each given area of studies.

Due to this, much methodological work is required to implement the plans for improving the higher education system. To ensure technical implementation of the higher education reform in Europe in accordance with the Bologna Process, an international project was launched under the title "Tuning Educational Structures in Europe" - TUNING. ${ }^{1}$ Its integral part is the project

${ }^{1}$ Ivan Djukaev, Evgeniya Karavaeva, and Elena Kovtun, eds., Tuning educational structures in Europe (Bilbao: University of Deusto Press, 2010). 
TUNING RUSSIA. ${ }^{2}$ It is intended to promote modernisation of the educational system in line with international trends, with the account of Russia's cultural and educational traditions, to help universities in solving difficult problems that arise in the course of globalisation of education. Lobachevsky State University of Nizhni Novgorod (UNN) is an active participant in the TUNING RUSSIA project. The methodology of this project, which summarizes the experience of specific steps in the development of core educational programs that meet the requirements of the Bologna process, has been successfully used in the UNN to reform a number of educational areas, primarily in the field of information and communication technology.

The purpose of this article is to analyse the experience of modernisation of educational programs for bachelors based on the TUNING methodology using the example of the area of studies "Fundamental computer science and information technology" (FCSIT) implemented at Lobachevsky State University of Nizhni Novgorod. The algorithm of curriculum reform in accordance with the TUNING methodology for the subject area of information technology is presented, along with the guidelines on educational programme development.

Bachelors FCSIT programme at UNN is aimed at training graduates capable of working in various industry and business organisations engaged in the creation, development and use of systems, products and services of information technology, such as international and domestic IT corporations: Intel, Microsoft, Teleca (Telma), IBM, T- platforms, Sun, Cisco, EMC, Nividia, Tesis, IT Academy. Such graduates should be also ready to work in research centres, educational institutions, various government bodies, including those in the Nizhni Novgorod region. The main objective of the programme modernisation was to reflect better the needs of the regional labour market, employers' requests, opportunities offered by research and human potential as well as the material infrastructure, ensuring academic mobility of students and teachers, implementing the student-centred approach, integration of UNN into a common European educational space. To achieve this goal, we applied the principles recommended by the TUNING project.

One of the most important features of the present stage in the of development of higher professional education in the framework of the Bologna process is that the requirements for the results of an educational programme are formulated in terms of "competences" of the graduate of this program. Competence is a comprehensive characteristic of a graduate's readiness to apply knowledge, skills and personal qualities in standard and

${ }^{2}$ Aurelio Villa Sanches and Manuel Poblete Ruiz, eds., Competence-based learning: a proposal for the assessment of generic competences. (Bilbao: University of Deusto Press, 2008). 
changing situations of professional activities. In the framework of the competence-based approach, it is possible to formulate the goal of education in the form of a system of competences, understandable to both students and employers, and to create a graduate's competence model. Therefore, developing a system of competences reflecting both domestic and international trends as well as the specific needs of the region is a central task in the modernisation of educational programs.

\section{Building a graduate's competence model}

The system of competences of Bachelors FCSIT programme was based on the profile developed in the course of implementation of the TUNING project by the subject area group (SAG) for Information and Communication Technology (ICT). ${ }^{3}$ The list of competences proposed by the ICT subject area group of the TUNING project has the following form: general $(\mathrm{g})$ and special (s) competences. These competences have been recommended by the TUNING project participants to develop core educational programs (CEPs) in the field of ICT.

In addition to this, recommendations of authoritative international ICT standards and some standards developed by the community of Russian ICT corporations were used in the development of the core educational programme. These include the Computing Curricula 2005 (CC2005), ${ }^{4}$ "The European e-Competence Framework" of the European Committee for Standardisation $^{5}\left(\mathrm{CEN}^{6}\right)$, and APKIT professional standards. ${ }^{7}$ It should be

${ }^{3}$ Ivan Djukaev, Evgeniya Karavaeva, Elena Kovtun, Milestones for the development and implementation of educational programmes in the subject area "Information and communication technologies, (Bilbao: University of Deusto Press, 2013), 43.

4 "IEEE/ACM Joint Task Force on Computing Curricula 2005. The Overview Report covering undergraduate degree programs in Computer Engineering, Computer Science, Information Systems, Information Technology Software Engineering, " Association for Computing Machinery, accessed January 28, 2014, http://www.google.ru/url?q=http://www. acm.org/education/curric_vols/CC2005-March06Final.pdf\&sa=U\&ei=gPxnU8-bM4LX4ATi qIEI\&ved=0CB0QFjAA\&sig2=FeC5yS_H7wU_A6JdNe_R4g\&usg=AFQjCNFT45ypN8VT FJXTHS94BHuJoESpVg

${ }^{5}$ Nadezhda Volpyan, "Adaptation and implementation of the European e-Competence Framework in Russia," Quality of education 9 (2011): 37.

6 "CEN Workshop Agreement. European e-Competence Framework 2.0. Part 1: A Common European Framework for ICT Professionals in All Industry Sectors," European e-Competence Framework, accessed January 28, 2014, http://www.ecompetences.eu//site/ objects/download/6197_rusCWA162341Part12010.pdf

7 "Professional standards in the field of information technology," AP-KIT, accessed January 28, 2014, http://www.apkit.ru/committees/education/meetings/standarts.php. 
noted that the SAG ICT profile was built on the basis of the classification of the subject area professional activity in accordance with the Computing Curricula 2005 (CC2005) standard. The European e-Competence Framework provides its list of professional competences in the field of ICT, where competences are divided into five groups corresponding to business processes in information systems: PLAN - BUILD - RUN ENABLE - MANAGE.

It should also be noted that in the development of a competence model of a graduate, in the case of UNN as a state institution of higher education, it was necessary to take into account the Federal State Educational Standards (FSES) of the Russian Federation for higher professional education, enacted in 2011. In accordance with the law of the Russian Federation "On Education", Lobachevsky State University of Nizhni Novgorod as a National Research University has been granted the right to develop its own self-imposed educational standards (SIES). In the first turn, these standards were created for areas of studies in ICT. In 2010, the first UNN standard was developed in the area of studies "010300 Fundamental Computer Science and Information Technology (FCSIT)" (Bachelor's degree), in 201, ${ }^{9}$ two more standards on FCSIT (Master's degree) and "Applied Computer Science" (ACS) (Bachelor's degree), and in 2012, ${ }^{10}$ a standard in the area of studies "Applied Computer Science" (Master's degree). The standards created were aimed at broadening and deepening the range of requirements of the Federal State Educational Standards in the relevant educational fields. The list of competences of these standards was mandatory in the formation of the core educational programme of Lobachevsky State University of Nizhni Novgorod. The competences of graduates, according to FSES and IEES, are also divided into two groups, similar to the competences of the TUNING project: general cultural competences (GCC) and professional competences (PC). The SIES competence framework for bachelors in the FCSIT programme has a complicated structure. Here, we outline integrated groups of competences, or meta-competences. Professional competences are grouped based on professional activity types specified in the APKIT professional standard: research activities, analytical activities, projects, production and technological activities, organisational and

\footnotetext{
${ }^{8}$ Russian Federal Law of 29 December 2012 N 273-FZ "On education in the Russian Federation" Article 2.

9 Victor Gergel, Evgeniya Gugina, and Oleg Kuzenkov, Development of the educational standard of the Nizhni Novgorod State University in the area of studies 'Fundamental Computer Science and Information Technology' (Moscow, 2010).

${ }^{10}$ Evgeniya Gugina and Oleg Kuzenkov, Using the TUNING methodology for development of educational standards of Lobachevsky State University of Nizhni Novgorod (Saratov: Saratov University Publishing House, 2012).
} 
managerial activities. A group of competences may contain several detailed competences.

When forming the competence model of a graduate, all these systems have been analysed and compared with each other. The summarised results of the comparison can be seen in Table 1 .

\section{Table 1}

\section{A comparison of European and Russian competence systems}

\begin{tabular}{|c|c|c|c|}
\hline $\begin{array}{l}\text { Competence groups of SIES } \\
\text { for Bachelors programme } \\
\text { (FCSIT) }\end{array}$ & $\begin{array}{c}\text { Competence groups of SIES } \\
\text { for Masters programme } \\
\text { (FCSIT) }\end{array}$ & SAG ICT competences & $\begin{array}{l}\text { CEN competences } \\
\text { (competence } \\
\text { groups) }\end{array}$ \\
\hline $\begin{array}{l}\text { The ability to } \\
\text { understand and } \\
\text { apply in research and } \\
\text { applied work the } \\
\text { modern mathematical } \\
\text { apparatus and the } \\
\text { basic laws of natural } \\
\text { science (PC } 3 \text { ). } \\
\text { The ability to } \\
\text { understand and } \\
\text { apply in practice } \\
\text { computational } \\
\text { mathematics and } \\
\text { the theory of in- } \\
\text { formation as a } \\
\text { fundamental scientific } \\
\text { basis of information } \\
\text { technology (PC 1). } \\
\text { The ability to conduct } \\
\text { research (PC 5). }\end{array}$ & $\begin{array}{l}\text { The ability to } \\
\text { understand and } \\
\text { develop mathematical } \\
\text { knowledge, the basic } \\
\text { laws of natural science } \\
\text { and basic principles } \\
\text { of information } \\
\text { technology (PC 1). }\end{array}$ & $\begin{array}{l}\text { s-11. Apply and } \\
\text { develop fundamental } \\
\text { and multidisciplinary } \\
\text { knowledge, including } \\
\text { mathematical and } \\
\text { scientific principles, } \\
\text { quantitative methods, } \\
\text { tools (including } \\
\text { software relevant } \\
\text { to their engineering } \\
\text { discipline) and } \\
\text { notations for successful } \\
\text { solving problems } \\
\text { s-6. Develop and } \\
\text { bring into effect new } \\
\text { competitive ideas in } \\
\text { the area of ICTs }\end{array}$ & \\
\hline $\begin{array}{l}\text { The ability to conduct } \\
\text { analytical activities } \\
\text { (PC 8). }\end{array}$ & $\begin{array}{l}\text { The ability to analyse } \\
\text { the subject area (PC 2); }\end{array}$ & $\begin{array}{l}\text { s-1. Analyse subject } \\
\text { area, identify, classify } \\
\text { and describe problems; } \\
\text { find the methods } \\
\text { and approaches for } \\
\text { their solving; define } \\
\text { requirements }\end{array}$ & \\
\hline $\begin{array}{l}\text { The ability to conduct } \\
\text { project activities (PC 7). }\end{array}$ & $\begin{array}{l}\text { The ability to design } \\
\text { information systems } \\
\text { (PC 3); }\end{array}$ & $\begin{array}{l}\text { s-2. Design ICT systems, } \\
\text { including modelling } \\
\text { (formal description) of } \\
\text { structure and processes }\end{array}$ & A. PLAN \\
\hline $\begin{array}{l}\text { The ability to } \\
\text { understand, } \\
\text { develop and apply } \\
\text { modern information } \\
\text { technology (PC 4). }\end{array}$ & $\begin{array}{l}\text { The ability to develop } \\
\text { information systems } \\
\text { (PC 4); }\end{array}$ & $\begin{array}{l}\text { s-3. Develop and } \\
\text { implement ICT systems }\end{array}$ & B. BUILD \\
\hline
\end{tabular}


Table 1

A comparison of European and Russian competence systems (continued)

\begin{tabular}{|c|c|c|c|}
\hline $\begin{array}{l}\text { Competence groups of SIES } \\
\text { for Bachelors programme } \\
\text { (FCSIT) }\end{array}$ & $\begin{array}{l}\text { Competence groups of SIES } \\
\text { for Masters programme } \\
\text { (FCSIT) }\end{array}$ & SAG ICT competences & $\begin{array}{l}\text { CEN competences } \\
\text { (competence } \\
\text { groups) }\end{array}$ \\
\hline $\begin{array}{l}\text { The ability to conduct } \\
\text { technological activities } \\
\text { (PC 9). }\end{array}$ & $\begin{array}{l}\text { The ability to deploy, } \\
\text { integrate, enter into } \\
\text { operation and service } \\
\text { information systems } \\
\text { and their elements } \\
\text { (PC 5); }\end{array}$ & $\begin{array}{l}\text { s-4. Deploy, install, } \\
\text { integrate, put into } \\
\text { service and maintain } \\
\text { ICT systems and their } \\
\text { elements }\end{array}$ & C. RUN \\
\hline \multirow{3}{*}{$\begin{array}{l}\text { The ability to conduct } \\
\text { organisational and } \\
\text { management activities } \\
\text { (PC 6). }\end{array}$} & $\begin{array}{l}\text { The ability to manage } \\
\text { IT projects (PC 6); }\end{array}$ & $\begin{array}{l}\text { g-5. Ability to design } \\
\text { and manage projects }\end{array}$ & E. MANAGE \\
\hline & $\begin{array}{l}\text { The ability to } \\
\text { assess, develop and } \\
\text { implement criteria } \\
\text { of quality, reliability } \\
\text { and efficiency of } \\
\text { information systems } \\
\text { (PC 7); }\end{array}$ & $\begin{array}{l}\text { s-5. Guarantee the } \\
\text { quality of information } \\
\text { systems according to } \\
\text { the requirements }\end{array}$ & $\begin{array}{l}\text { E6. ICT Quality } \\
\text { Management }\end{array}$ \\
\hline & $\begin{array}{l}\text { The ability to develop } \\
\text { and implemented } \\
\text { a strategy for } \\
\text { information security } \\
\text { management (PC 8); }\end{array}$ & $\begin{array}{l}\text { s-8. Analyse, choose } \\
\text { and apply methods } \\
\text { and tools to provide } \\
\text { information security }\end{array}$ & $\begin{array}{l}\text { E.8. Information } \\
\text { Security } \\
\text { Management }\end{array}$ \\
\hline \multirow[t]{3}{*}{$\begin{array}{l}\text { Readiness to } \\
\text { be included in } \\
\text { the professional } \\
\text { community (PC 2). }\end{array}$} & $\begin{array}{l}\text { The ability to solve } \\
\text { problems of } \\
\text { professional activity as } \\
\text { part of the research and } \\
\text { production team (PC 9); }\end{array}$ & $\begin{array}{l}\text { g-2. Ability to work in } \\
\text { a team }\end{array}$ & $\begin{array}{l}\text { E4. Relationship } \\
\text { Management }\end{array}$ \\
\hline & $\begin{array}{l}\text { The ability to } \\
\text { understand and apply } \\
\text { professional standards, } \\
\text { specifications, rules } \\
\text { and recommendations } \\
\text { in the field of } \\
\text { information } \\
\text { technology in one's } \\
\text { practical activities } \\
\text { (PC 10); }\end{array}$ & $\begin{array}{l}\text { s-7. Know, follow } \\
\text { and assess the degree } \\
\text { of compliance with } \\
\text { industry specifications, } \\
\text { standards, regulations, } \\
\text { and recommendations }\end{array}$ & \\
\hline & $\begin{array}{l}\text { The ability to organise } \\
\text { IT training (including } \\
\text { e-learning) (PC 11). }\end{array}$ & $\begin{array}{l}\text { s- } 10 \text {. Train and support } \\
\text { ICT users }\end{array}$ & $\begin{array}{l}\text { D3. Education } \\
\text { and Training } \\
\text { Provision }\end{array}$ \\
\hline
\end{tabular}


When comparing lists of competencies, we can see that some of them are essentially identical and differ either in the wording or in minor shades of meaning. A number of competences of the SIES in the SAG list were formulated in a more general manner. Some SAG ICT competences cover the content of several SIES competences. Several SAG competences had no direct correspondence in the list of SEIS competences, although one can find in the SEIS list some more general competences that assume the mastery of SAG ICT competences. It should be noted that the European e-Competence Framework contains no competences related to research activities in the field of ICT. This is not surprising, since originally this Framework did not cover such type of activities. Moreover, the European Framework does not contain any competences relating to the graduates' analytical work. In comparison with other competence systems, this is a disadvantage, and the Framework needs to be improved.

On the other hand, in the SAG ICT and SEIS system of competences, there are some competence groups, which in the European e-Competence Framework are represented by specific competences included in larger groups. Evidently, when developing educational programs and profiles, it would be appropriate to further enlarge these competences and to integrate them with other groups in meta-competences.

When forming the competence model of a graduate, it was necessary to fulfil the requirements of the standard, but at the same time it had to be supplemented with the competences recommended by the TUNING project. In the wording of SIES competences that have similar counterparts in the SAG list, the wording used by SAG was used, especially in those cases where it allowed a more general interpretation. Those SAG competences that did not have direct counterparts in the SIES were added to corresponding SIES competence groups. Finally, the list of SIES competences was supplemented with s-11 competence, in relation to which PC1, PC3 and PC4 competences can be considered as a group. On the other hand, detailed SIES competences were related to TUNING competences in accordance with the profile to identify the dynamic relationships between them. Generalisation and integration of definitions and requirements of the SIES and the FSES was performed. At the same time, they were expanded and provided with more details, taking into account specific conditions in which the standard is applied.

This work received extensive support from experts representing enterprises where UNN graduates are employed. To analyse and evaluate the model of a graduate, employees of leading IT corporations and enterprises were recruited, first of all, of those companies that are represented in the Nizhni Novgorod region: Intel, Teleca, Sedakov Research Institute of 
Measuring Systems, Federal Nuclear Centre, Nizhni Novgorod Centre of New Information Technologies, etc.

After a detailed analysis, requirements were formulated to the results of mastering the CEP of Nizhni Novgorod State University (Bachelor's degree in the area of studies "Fundamental computer science and information technology") in the form of a profile, which is a system of interrelated competences.

\section{Developing competence maps}

For each competence, a competence map was developed. The TUNING methodology for competence mapping involves the description of particular competences by means of a set of indicators that show specific qualitative aspects in the mastering of the given competence. Besides, several levels of competence achievement are identified. At each level, the quantitative degree of mastering each indicator is characterized by descriptors. In most cases, five indicators, two or three skill levels and five descriptors are used to build a competence map.

Levels of mastery were determined based on the following principles: the first level corresponds to the level of technical literacy, or the lowest level of performance; the second level corresponds to the level of understanding the concepts and the ability to use them, this is the level of middle-tier managers; while the third level corresponds to the level of in-depth detailed mastery, which is the level of experts. In addition to this, learning objectives were identified for each competence.

Let us illustrate the construction of the competence map using the example of the general cultural competence "The ability for abstract thinking, analysis and synthesis." Three indicators have been identified for this competence:

1. The ability to analyse situations and systems;

2. The ability to use logical inference procedures;

3. The ability to synthesize a model of and find a solution to a problem situation.

Three levels of competence development have also been identified. These levels do not directly correspond to the year of studies, but they reflect the goals and objectives of the students' progression (in terms of competence development) in respective disciplines. Such goals and objectives are stated in the program of the course. 
1. Using elementary logical procedures for understanding a particular system or situation

2. Command of technical support tools for analysis and synthesis

3. Using logical analysis of the real-life situation or case to find the optimal solution and generate new ideas.

At each level, the indicators have been appropriately specified:

Level 1:

- Analysis of a real-life system or situation in order to identify the main components and determinants;

- Using elementary logical inference procedures;

- Establishing relationships between the constituent elements and factors of a particular system or situation.

Level 2:

- Command of basic technical analysis tools and their application in the analysis of concrete situations and cases;

- Command of basic laws of formal logic;

- Command of mathematical and computer simulation techniques for the synthesis of models of real-life systems.

Level 3:

- Command of system analysis techniques;

- Using logical procedures for obtaining new knowledge;

- Using models of real-life systems for the synthesis of optimal solutions in problem situations.

For example, for the first level indicator "Analysis of a real-life system or situation in order to identify the main components and determinants", the descriptor system has the following form:

1. The student does not identify main components and determinants of a particular system or situation.

2. The student makes mistakes in identifying the main constituents and determinants of a particular system or situation.

3 . The student correctly identifies all the determinants and components of a particular system or situation.

4. The student classifies the main factors and components of a particular system or situation in order of importance.

5. The student compares the analysis of a specific system with the analysis of similar systems using previous experience to analyse a particular system. 
The degree of competence achievement at each level for each indicator was assessed using five descriptors. Descriptors specify the degree of achievement of the indicator corresponding to each skill level. To develop a system of descriptors, their qualitative and quantitative content was determined, as shown in Table 2. The proposed system of descriptors reflects traditional Russian practices with the account of European recommendations. The qualitative aspect of the descriptor indicates the degree of achievement of the indicator (competence). The qualitative component in some cases gives an opportunity to compare quantitative results (answer, test, control task, etc.) with the appropriate descriptor.

\section{Table 2}

Descriptors for degrees of competence achievement

\begin{tabular}{|c|c|c|c|}
\hline Descriptors & Qualitative description & $\begin{array}{c}\text { Quantitative } \\
\text { evaluation } \\
\text { (as a percentage } \\
\text { of fulfilment } \\
\text { of a control task, } \\
\text { test, etc.) }\end{array}$ & $\begin{array}{l}\text { Correspondence } \\
\text { to UNN grading } \\
\text { system }\end{array}$ \\
\hline 1 & $\begin{array}{l}\text { A given level of competence has not been } \\
\text { achieved at all. Total lack of mastery of the } \\
\text { material. }\end{array}$ & $0-20 \%$ & Poor \\
\hline 2 & $\begin{array}{l}\text { The degree of achievement of a given level of } \\
\text { competence is not sufficient to achieve the main } \\
\text { goals of education; significant errors are made. }\end{array}$ & $20-50 \%$ & Unsatisfactory \\
\hline 3 & $\begin{array}{l}\text { Minimum allowable degree of achievement of } \\
\text { a given level of competence needed to achieve } \\
\text { the main goals of education. Some mistakes } \\
\text { can be made, which are not critical for the } \\
\text { achievement of this level. } \\
\text { Knowledge of the minimum material required } \\
\text { in the given subject, with a number of errors; } \\
\text { the ability to solve main problems. }\end{array}$ & $50-70 \%$ & Satisfactory \\
\hline 4 & $\begin{array}{l}\text { Competence level achieved in general. } \\
\text { Sufficient knowledge of basic material with } \\
\text { some errors, ability to solve a wide range of } \\
\text { standard problems }\end{array}$ & $70-90 \%$ & $\begin{array}{c}\text { Good - } \\
\text { Very Good }\end{array}$ \\
\hline 5 & $\begin{array}{l}\text { Competence level fully achieved, above } \\
\text { mandatory requirements, the qualities } \\
\text { associated with the manifestation of a given } \\
\text { level of competence in a wide range are } \\
\text { demonstrated. Connection with the formation } \\
\text { of other competences is manifested. } \\
\text { Excellent knowledge of the main and additional } \\
\text { material without mistakes and errors. The ability } \\
\text { to solve additional problems of high complexity. }\end{array}$ & $90-100 \%$ & $\begin{array}{c}\text { Excellent - } \\
\text { Perfect }\end{array}$ \\
\hline
\end{tabular}


The system of descriptors thus constructed provides the basis for developing assessment materials to monitor the development of each competence. This system is based on UNN's seven-point grading system that has been used successfully for 10 years and provides a more flexible approach to the reflection of students' performance. UNN's system of grades is consistent with European practices; it facilitates the integration of the university in the European educational space and includes the following grades:

- "Perfect": the student displays in-depth knowledge of the main and additional material without any mistakes and errors, can solve nonstandard problems, has acquired all the competences (parts of competences) relating to the given subject in a comprehensive manner and above the required level. A stable system of competences has been formed, interrelation with other competences is manifested.

- "Excellent": the student displays in-depth knowledge of the main material without any mistakes and errors, has acquired all the competences (parts of competences) relating to the given subject completely and at a high level, a stable system of competences has been formed.

- "Very good": the student has sufficient knowledge of the main material with some minor mistakes, can solve standard problems and has acquired completely all the competences (parts of competences) relating to the given subject.

- "Good": the student has the knowledge of the main material with some noticeable mistakes and has acquired in general the competences (parts of competences) relating to the given subject).

- "Satisfactory": the student has the knowledge of the minimum material required in the given subject, with a number of errors, can solve main problems, the competences (parts of competences) relating to the subject are at the minimum level required to achieve the main learning objectives.

- "Unsatisfactory": the knowledge of the material is insufficient, additional training is required, the competences (parts of competences) relating to the subject are at a level that is insufficient to achieve the main learning objectives.

- "Poor" - lack of knowledge of the material, relevant competences have not been acquired.

Thus, the use of the TUNING technology can help to significantly upgrade the learning and teaching process and provides effective tools for the development of self-imposed standards and core educational programs based on them. 
The development of a core educational programme can be considered on the example of our English-medium Bachelors FCSIT programme. It should be noted that the UNN has some experience of teaching students in English. Since 2006, a Bachelors programme in Information Technology with intensive use of English has been run by the university in the framework of the second-generation state educational standards. English-speaking students from different countries were enrolled in this programme. In 2011, the first four Bachelors graduated from this programme, in 2012, the second class of 10 students graduated with Bachelor's degrees. ${ }^{11}$ Teaching in English is aimed at facilitating the learning of the programme material by international students, at increasing academic mobility and creating additional advantages for alumni's active participation in international activities. Implementation of programmes of separate disciplines and the core educational programme in foreign languages makes it possible to attract leading foreign experts to reading lectures and to teaching international students. Upgrading the programme is of paramount importance for ensuring academic mobility and for the university's inclusion in the European educational space.

\section{Modular structure of the curriculum}

Modular organisation of the curriculum makes it possible to improve the structure of the students' independent work, and to achieve a more uniform distribution of the workload of students' independent work over the modules, on the one hand, and a flexible distribution of the workload with respect to individual subjects and topics of the module.

Modules are relatively independent parts of the educational program. Each module is a formally structured learning unit intended to formation a certain competence or a group of related competences. It includes a logically complete part of the learning material, the targeted programme of actions and methodological guidelines for achieving the goals of the module. The module may contain a portion of some discipline, or one or more related disciplines or parts of such disciplines. The module includes the following components: a description of the goals and objectives with respect to the content; learning outcomes (knowledge, skills, and transferable competences); strategies for teaching/learning; assessment/certification procedures; a

${ }^{11}$ Alexander Bedny et al., "Main educational program for a Bachelor degree in the area of studies "Fundamental computer science and in-formation technology" in English" Vestnik of UNN 6, no. 1 (2012): 12. 
description of student workload; admission requirements. Each module must be provided with instructional documentation.

Modular organisation of the learning process assumes that there may be five to six modules in each semester. The workload required to learn the material of one module in the framework of the programs developed is assumed to be five credit units. According to the Russian educational standards, one credit unit is equal to 36 academic hours. If a module consists of several academic disciplines or parts of disciplines, it is possible to credit students separately for each discipline, which makes part of the module. Each module is concluded with an interim certification, which includes an examination and/or a test. Within the module, a term project or a term paper may be performed. Classroom work may constitute up to $3 / 5$ of the module volume. Within the modules, some subjects may be selected by students.

Out-of-classroom work of students within the module can be implemented in the following ways: doing their homework, working on their term papers and projects, preparation of a literature review on a specific topic, preparation of an essay, participation in seminars and research projects, implementation of research on relevant topics, conducting lectures, interactive workshops and consultations using distance learning technologies (DLT), preparation for interim certification. Out-of-classroom work of students should be provided with instructional materials; it should be monitored for workload and assessed by a teacher or a research supervisor. The assessment of the progress may be carried out both in classroom and during extracurricular work (this includes the assessment with the use of DLT means). Up to 50\% of the independent work planned as part of this module may be assessed by faculty members. For organising and controlling independent work, contact hours may be allocated in addition to the primary teaching load. At the discretion of the teacher, necessary premises and time (apart from regular classes) may be allocated for the control of independent work. At least 1 credit in each module must be devoted to the preparation and passage of an interim certification. Interim certification is carried out in the following forms: examination, test, graded test. Examinations are held during the time of examination sessions. Tests may be conducted during the semester, based on current progress.

In each semester, one module is allocated for the study of the humanities and socio-economic disciplines. These modules include: "History", "Philosophy", "Sociology", "Economics", "Health, Wellness and Safety", "Social and Ethical Issues of Information Technology", "Concepts of Modern Natural Science". Every such module also includes practical Russian language classes (for international students, Russian is considered a foreign language). As a result of training under this program, Bachelors must read and speak Russian fluently (the knowledge of English is assumed a priori). 
Within each of the humanities module, one general cultural (general) competence is developed, for example, in the module "Philosophy", the competence "Understand and analyse the ideological, socially and personally meaningful philosophical problems" (GC1.1); in the module "Life safety", the competence "Knowledge of the basic principles of protection of workers and the public from accidents, natural disasters and their possible consequences" (GC3.4).

In each semester, there are some modules of the mathematics and sciences cycle. These modules are primarily aimed at developing professional (special) competence "The ability to understand and apply modern mathematical apparatus and basic laws of natural science in research and applications" (PC3). These include "Mathematical Analysis", "Geometry and Algebra", "Discrete Mathematics", "Graph Theory", "Theory of Probability and Mathematical Statistics", "Physics", "Differential Equations", "Optimization Techniques", "Computational Mathematics and Functional Analysis", "Operations Research". Furthermore, within these mathematical modules (except for "Physics"), the competence "The ability for abstract thinking, analysis and synthesis" is developed. The aim of the modules "Mathematical Analysis", "Geometry and Algebra", "Discrete Mathematics", "Graph Theory", "Probability Theory and Mathematical Statistics" and "Differential Equations" is to develop the above-mentioned competence at the second level of mastery ("Command of technical support tools for analysis and synthesis"); the remaining modules are aimed at developing this competence at the third level of mastery ("Using logical analysis of a real-life situation or event to find the optimal solution and generate new ideas").

In addition to this, it is mandatory to have in each semester some modules of the professional cycle, such as "Introduction to Programming", "Programming Languages", "Operating Systems", "Computer Networks", "Logic Programming", "Computer Systems", "Parallel Programming" "Databases", "Analysis and Development of Algorithms", "Information Systems", "Software Engineering", "Computer Graphics", "Supercomputers" and some others. These modules are aimed at developing appropriate professional competences, as a rule, at the first mastery level (during the first and second years of studies) or at the second level (third and fourth years of studies).

The schedule of studies consists of eight semesters. The duration of the period of theoretical studies in each semester is 18 weeks (except the 8th semester). The duration of the examination session in each semester is 5 weeks (except the 8th semester).

The workload of the in-house practical training is 14 credits. It is evenly distributed during the first four semesters of studies. At the end of 
the in-house practical training in each semester, there is a test (pass/no pass or rated). The in-house practical training is carried out in the form of computer practice in the main courses of the basic and the variable parts of the professional training cycle. In-house practical training is carried out in the laboratories of the University according to a separate schedule, which is coordinated with the schedule of theoretical studies, with direct participation and under the guidance of the teacher responsible for practical training.

The workload of the field practical training is 5 credits. It is carried out during the seventh semester. The field practical training constitutes a separate module of CEP and may take place at UNN's departments and laboratories that have the necessary personnel, expertise and equipment, or at the leading enterprises of IT industry with offices and facilities in Nizhni Novgorod, where all the necessary conditions are created for the successful acquisition of skills in the real-life production mode. The conduct of field practical training is governed by appropriate contracts for providing practical training base between the University and the following organisations.

For all types of practical training, one day a week is allocated during the period of theoretical studies. Practical training is supported with all the necessary material and technical resources (computer rooms, laboratories, software and other types of support).

Each student is provided with access to e-library systems "University Online Library" and "Lan" containing publications on main subjects to be studied. The libraries are formed in coordination with copyright owners of educational and instructional materials.

The educational process is provided by 12 specialised laboratories, a high-performance cluster with peak performance of 17,5 trillion operations per second, 3 personal mini-clusters, National Instruments equipment for laboratory practicum on the concepts of modern natural science, computer graphics and virtual reality equipment (including 3D), equipment for 3D-prototyping. The equipment has been installed for the access gateway for connecting the high-performance cluster to the Russian grid network.

\section{Implementation of the student-centred approach in education}

In implementing the CEP, an adequate socio-cultural environment is formed and necessary conditions are created for all-round personality development. The student-centred approach, as implemented in UNN, is based upon the UNN policies and Russian traditional practices in higher education. Some additional elements have been incorporated specifically for 
international students who are not familiar with such practices and traditions in the Russian system of education.

In the course of the Bachelors programme, students are given the opportunity to engage in physical training and sports, including sport games, with the total amount of not less than 400 hours. These classes are distributed evenly over the first four semesters. Every week, there are four hours of physical training and sports in the schedule of classes. The rest of the physical training and sports classes are organised outside the schedule of regular classes. The university monitors the use by each student of the opportunities provided for physical education and sports. As an alternative, students' participation in sports circles and sections, visiting gyms and stadiums may be counted towards credits in this discipline.

The University contributes to the improvement of the social and educational component of the learning process through the development of student self-government; providing students with group curators from the faculty (junior years) and individual scientific supervisors (starting from the third year); enabling critical evaluation by the students of the content, organisation and quality of the educational process in general and with regard to the work of individual teachers; enabling participation of students in public organisations, sport and art clubs, student scientific societies.

The monitoring of the workload of students' independent work, evaluation of the success of the educational process, of the process of competence formation, and of the work done by individual teachers is carried out by means of a systematic survey of students using respective questionnaires.

Students participate in the shaping of their individual educational trajectory by choosing elective academic disciplines (modules, classes) or optional disciplines (modules, classes), research topics, academic disciplines (modules, classes) offered by their departments on the subject of research, research supervisors (tutors), location of their in-house and field practical training, and the subject of their field training.

Final State certification of university graduates is compulsory. It takes place after the CEP has been completed in full. Final state certification is held at the end of the $8^{\text {th }}$ semester and includes an interdisciplinary State examination and the defence of the final qualification paper (Bachelor's thesis). The Bachelor's thesis is prepared and presented in English. It must be accompanied by an abstract in Russian. Preparation for the State examination is supported by review lectures in all the disciplines included in the examination program, and by consultations given by leading teachers. The total workload of the Final State certification is 12 credit units. 
Upon completion of their studies, bachelors are issued a standard form Diploma in Russian, and may also be issued a European Diploma Supplement in English in compliance with the model developed by the European Commission, Council of Europe and UNESCO.

\section{Conclusions}

Thus, using the methodology of the TUNING project, we have been able to achieve substantial modernisation of the educational process and to develop an innovative educational programme for bachelors in the area of studies "Fundamental computer science and information technology", which testifies to the high efficiency of this methodology and its importance in the renewal of higher education. ${ }^{12}$

Based on this experience, we can indicate the basic fundamental aspects in the reform of educational programmes with the use of the TUNING methodology:

1. Development of a graduate competence model based on the analysis of international and national guidelines and standards.

2. Active involvement of employers (both at the international level (multinational corporations) and at the national, primarily regional, level) in the formulation of the learning objectives.

3. Supporting the competence model with competence maps and a system of learning objectives in order to form a pool of teaching and learning tools and a pool of learning assessment tools.

4. Development of the curriculum on a modular basis.

5. Empowering students to influence the learning process and the formation of an individual educational trajectory.

\section{Bibliography}

AP-KIT. "Professional standards in the field of information technology." Accessed January 28, 2014. http://www.apkit.ru/committees/education/meetings/ standarts.php

Association for Computing Machinery. "IEEE/ACM Joint Task Force on Computing Curricula 2005. The Overview Report covering undergraduate

12 "An algorithm for curriculum reform on information technology in accordance with the TUNING technology," Lobachevsky State University of Nizhni Novgorod, accessed January 28, 2014, http://www.unn.ru/elibrary/methodmaterial.html?pscience=11. 
degree programs in Computer Engineering, Computer Science, Information Systems, Information Technology Software Engineering." Accessed January 28, 2014. http://www.google.ru/url?q=http://www.acm.org/education/curric vols/CC2005-March06Final.pdf\&sa=U\&ei=gPxnU8-bM4LX4ATiqIEI\&ved $=0 \mathrm{CB} 0 \mathrm{QFj}$ AA\&sig $2=\mathrm{FeC} 5 \mathrm{yS} \_\mathrm{H} 7 \mathrm{wU} \_\mathrm{A} 6 \mathrm{JdNe} \_\mathrm{R} 4 \mathrm{~g} \& \mathrm{usg}=\mathrm{AFQ}$ jCNFT45ypN8VTFJXTHS94BHuJoESpVg

. "CEN Workshop Agreement. European e-Competence Framework 2.0. Part 1: A Common European Framework for ICT Professionals in All Industry Sectors.” Accessed January 28, 2014. http://www .ecompetences.eu//site/objects/ download/6197_rusCWA162341Part12010.pdf

Bedny, Alexander Victor Gergel, Liliya Erushkina, and Oleg Kuzenkov. "Main educational program for a Bachelor degree in the area of studies 'Fundamental computer science and in-formation technology' in English." Vestnik of UNN 6, no. 1(2012): 11-15.

Djukaev, Ivan, Evgeniya Karavaeva, and Elena Kovtun. Milestones for the development and implementation of educational programmes in the subject area "Information and communication technologies. University of Deusto Press: Bilbao, 2013

- Tuning educational structures in Europe. Bilbao: University of Deusto Press, 2010.

Gergel, Victor, Evgeniya Gugina, and Oleg Kuzenkov. Development of the educational standard of the Nizhni Novgorod State University in the area of studies "Fundamental Computer Science and Information Technology. Moscow, 2010 .

Gugina, Evgeniya, and Oleg Kuzenkov. Using the TUNING methodology for development of educational standards of Lobachevsky State University of Nizhni Novgorod. Saratov: Saratov University Publishing House, 2012.

Lobachevsky State University of Nizhni Novgorod. "An algorithm for curriculum reform on information technology in accordance with the TUNING technology." Accessed January 28, 2014. http://www.unn.ru/elibrary/methodmaterial. html?pscience $=1$.

Russian Federal Law of 29 December 2012 N 273-Ф3 “On education in the Russian Federation" Article 2.

Villa Sanches, Aurelio, and Manuel Poblete Ruiz. Competence-based learning: $a$ proposal for the assessment of generic competences. Bilbao: University of Deusto Press, 2008.

Volpyan, Nadezhda. "Adaptation and implementation of the European e Competence Framework in Russia”, Quality of education 9 (2011): 36-39. 